\title{
Calcite-Aragonite Speleothems from a Hand-Dug Cave in Northeast Kansas
}

By Frederic R. Siegel ${ }^{1}$ ) and Wakefield Dort, Jr. ${ }^{2}$ )

With one figure in the text

Recently, the writers were informed that a speleothem-containing cave was present in Doniphan County (Section 2 NENW, Township 2S, Range $22 \mathrm{E}$ ), Northeast Kansas. A field trip to the area and an informative conversation with the cave owner, Mr. Oliver Propheter, aided us in locating the cave in the bluff overlooking the Missouri River. The cave was apparently hand-dug in a Pennsylvanian shale below a dolomitic cap-rock and is estimated to be between 150 and 200 years old. Local lore has it that American Indians originally excavated the cave and that during the Civil War and thereafter, the same cave was frequently used as a hiding place. It was reported to at one time have been high enough for a man to stand in. At present, the cave is about 12 meters long, two meters wide, and one meter high. Slumping from the sides has caused considerable filling.

Speleothems are present throughout the cave in the form of stalactites (straws and solid), linear stalactitic growths, flowstone, ceiling crust, and popcorn growths around pieces of the ceiling rock that have fallen into a pool of standing water in the back part of the cave. Maximum stalactite length is about three centimeters and crusts and flowstone have thicknesses of about one to three millimeters. If the estimated age of the cave is correct (i.e., 150 to 200 years old), the maximum rate of stalactite growth along the stalactite vertical axis is about 0.20 to 0.15 millimeters per year. Moore (1962) notes that the rate of stalactite growth is variable, but that it never exceeds several millimeters per year; he also states that unpublished observations

\footnotetext{
1) Department of Geology, The George Washington University, Washington, D.C.

2) Department of Geology, The University of Kansas, Lawrence, Kansas.
} 
suggest that the average rate of stalactite elongation is about a quarter of a millimeter a year. Radiocarbon data (Broecker and others, 1960) give a growth rate of 0.06 millimeters a year for a stalagmite from Moaning Cave, California. The growth rate given in this study, 0.15 to 0.20 millimeters per year, is consistent with the estimates given above and those given in Table 1.

X-ray diffraction determinations of the speleothem mineralogy showed that the stalactites contain only calcite and aragonite with calcite being the dominant mineral (Figure $1 \mathrm{a}$ ). The flowstone and ceiling crust have this same mineralogy but contain detrital siliceous impurities (Figures $1 \mathrm{~b}$ and $1 \mathrm{c}$ ). Linear stalactitic growths have aragonite as the major carbonate mineral (Figure $1 \mathrm{~d}$ ). A small pool of water exists in the rear of the cave and pieces of the ceiling rock which had dropped into the pool in the past are now enclosed by a popcorn type growth which is 100 percent calcite (Figure 1e).
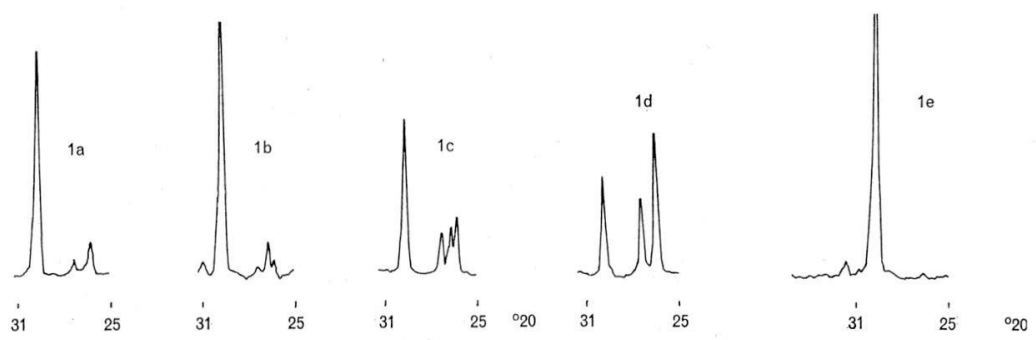

Figure 1.

X-ray diffractogram of selected speleothems from Propheter's Cave, Doniphan County, Northeast Kansas.

Qualitative emission spectrograph analyses of the ceiling rock, the encrusted wall rock (shale), and the different speleothem types, are given in Table 2. It should be mentioned that the dolomitic nature of the overlying carbonate ceiling rock is reflected in the slightly higher $2 \varnothing$ position of the major carbonate diffraction peaks of the speleothems. A most interesting aspect of the chemical data is the apparent high concentration of strontium in the fresh cap-rock and in the speleothems. As noted in other studies, strontium tends to be more abundant where aragonitic material is more abundant (White, personal communication; Siegel, 1965). However, the fact that strontium is 


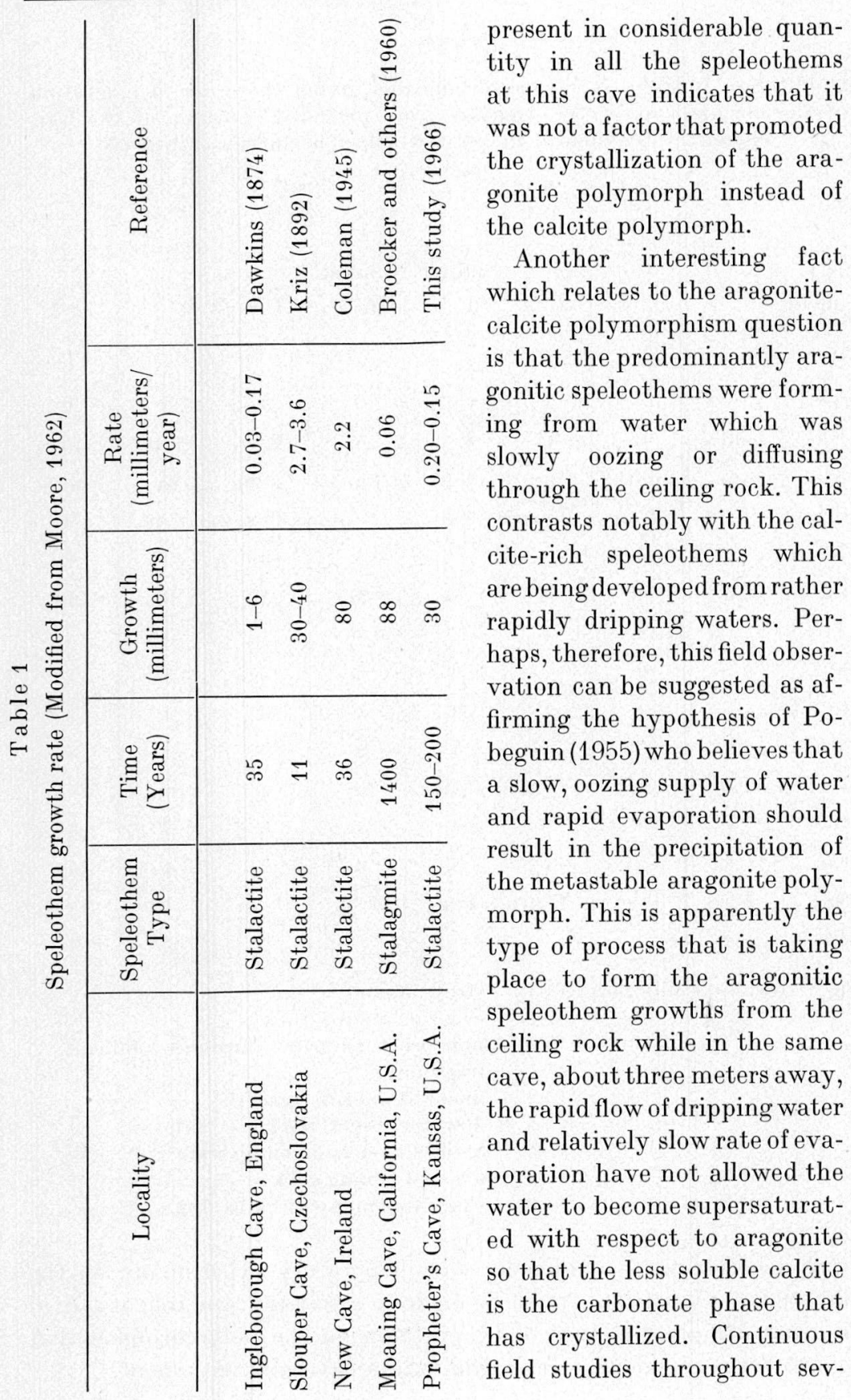


Table 2

Qualitative emission spectrograph analyses giving the order of magnitude of the elements observed. Analyses were provided courtesy of the Geochemistry Division of the State Geological Survey of Kansas

$$
\begin{array}{ll}
\mathrm{t}=<0.1 \% & \mathrm{~m}=10 \% \\
\mathrm{~T}=0.1-1 \% & \mathrm{M}=>10 \%
\end{array}
$$

\begin{tabular}{l|c|c|c|c|c|c|c|c}
\hline \multirow{2}{*}{$\begin{array}{c}\text { Ele- } \\
\text { ment }\end{array}$} & $\mathrm{C}-\mathrm{t}$ & $\mathrm{C}-2$ & $\mathrm{C}-3$ & $\mathrm{C}-\mathrm{t}$ & $\mathrm{C}-5$ & $\mathrm{C}-6$ & $\mathrm{C}-7$ & $\mathrm{C}-8$ \\
\hline $\mathrm{B}$ & $\mathrm{t}$ & $\mathrm{t}$ & $\mathrm{t}$ & - & $\mathrm{t}$ & - & $\mathrm{t}$ & $\mathrm{t}$ \\
$\mathrm{Na}$ & $\mathrm{T}$ & $\mathrm{T}$ & $\mathrm{T}$ & $\mathrm{t}$ & $\mathrm{T}$ & $\mathrm{t}$ & $\mathrm{T}$ & $\mathrm{T}$ \\
$\mathrm{Mg}$ & $\mathrm{m}$ & $\mathrm{m}$ & $\mathrm{m}$ & $\mathrm{T}-\mathrm{m}$ & $\mathrm{m}$ & $\mathrm{T}-\mathrm{m}$ & $\mathrm{T}-\mathrm{m}$ & $\mathrm{m}$ \\
$\mathrm{Al}$ & $\mathrm{m}$ & $\mathrm{m}$ & $\mathrm{m}$ & $\mathrm{T}-\mathrm{m}$ & $\mathrm{m}$ & $\mathrm{T}-\mathrm{m}$ & $\mathrm{m}$ & $\mathrm{m}$ \\
$\mathrm{Si}$ & $\mathrm{T}-\mathrm{m}$ & $\mathrm{T}-\mathrm{m}$ & $\mathrm{T}-\mathrm{m}$ & $\mathrm{T}$ & $\mathrm{T}-\mathrm{m}$ & $\mathrm{T}-\mathrm{m}$ & $\mathrm{T}-\mathrm{m}$ & $\mathrm{M}$ \\
$\mathrm{K}$ & $\mathrm{t}$ & $\mathrm{t}$ & - & - & $\mathrm{t}$ & $\mathrm{t}$ & $\mathrm{T}$ & $\mathrm{T}$ \\
$\mathrm{Ca}$ & $\mathrm{M}$ & $\mathrm{M}$ & $\mathrm{M}$ & $\mathrm{M}$ & $\mathrm{M}$ & $\mathrm{M}$ & $\mathrm{m}$ & $\mathrm{m}$ \\
$\mathrm{Ti}$ & $\mathrm{t}$ & $\mathrm{t}$ & $\mathrm{t}$ & - & $\mathrm{t}$ & - & $\mathrm{t}$ & - \\
$\mathrm{V}$ & $\mathrm{t}$ & $\mathrm{t}$ & $\mathrm{t}$ & $\mathrm{t}$ & $\mathrm{t}$ & $\mathrm{t}$ & $\mathrm{t}$ & $\mathrm{t}$ \\
$\mathrm{Cr}$ & $\mathrm{t}$ & $\mathrm{t}$ & $\mathrm{t}$ & $\mathrm{t}$ & $\mathrm{t}$ & $\mathrm{T}$ & $\mathrm{t}$ & $\mathrm{t}$ \\
$\mathrm{Mn}$ & $\mathrm{t}$ & $\mathrm{T}$ & $\mathrm{t}$ & $\mathrm{t}$ & $\mathrm{t}$ & $\mathrm{T}$ & $\mathrm{t}$ & $\mathrm{T}$ \\
$\mathrm{Fe}$ & $\mathrm{T}-\mathrm{m}$ & $\mathrm{m}$ & $\mathrm{T}-\mathrm{m}$ & $\mathrm{T}-\mathrm{m}$ & $\mathrm{m}$ & $\mathrm{m}$ & $\mathrm{m}$ & $\mathrm{T}-\mathrm{m}$ \\
$\mathrm{Ni}$ & $\mathrm{t}$ & $\mathrm{t}$ & - & $\mathrm{t}$ & $\mathrm{t}$ & $\mathrm{t}$ & $\mathrm{T}$ & $\mathrm{t}$ \\
$\mathrm{Cu}$ & $\mathrm{t}$ & $\mathrm{t}$ & $\mathrm{t}$ & $\mathrm{t}$ & $\mathrm{t}$ & $\mathrm{t}$ & $\mathrm{t}$ & $\mathrm{t}$ \\
$\mathrm{Sr}$ & $\mathrm{T}-\mathrm{m}$ & $\mathrm{T}-\mathrm{m}$ & $\mathrm{T}-\mathrm{m}$ & $\mathrm{T}-\mathrm{m}$ & $\mathrm{T}-\mathrm{m}$ & $\mathrm{T}-\mathrm{m}$ & $\mathrm{t}$ & $\mathrm{t}$ \\
$\mathrm{Pb}$ & - & - & - & - & - & - & $\mathrm{t}$ & $\mathrm{t}$
\end{tabular}

Key to sample numbers: $\mathrm{C}-1=$ straw stalactite

$\mathrm{C}-2=$ crust on ceiling rock

$\mathrm{C}-3=$ popcorn type growth around a fallen fragment

$\mathrm{C}-\mathbf{4}=$ linear stalactitic growth

$\mathrm{C}-5=$ flowstone over wallrock shale

$\mathrm{C}-6=$ fresh, unleached ceiling rock

$\mathrm{C}-7=$ leached ceiling rock

C-8 $=$ shale in which cave was dug

eral field seasons, complemented by laboratory experiments on the kinetics of evaporation, must be made to assess the true role of rate of solution supply and rate of evaporation on the polymorphism that exists between calcite and aragonite in a cavern environment. 


\section{SUMMARY}

Speleothems in the form of stalactites, linear stalactitic growths, flowstone, and crusts, from a hand-dug cave in Northeast Kansas (Sec. 2 NENW, T $2 \mathrm{~S}, \mathrm{R} 22 \mathrm{E}$ ) are composed of calcite and aragonite. If the estimated age of the cave is correct, i.e., 150 to 200 years old, the stalactites have grown at a maximum rate of 0.20 to 0.15 millimeters per year along their vertical axes. All of the speleothems examined contain about one percent strontium (based on qualitative emission spectrograph analyses). Rate of supply and evaporation of the vadose waters may dictate whether aragonite or calcite is the polymorph that precipitates from the cave waters.

\section{RESUMEN}

Espeleotemas en forma de estalactitas, crecimientos estalactíticos lineales, travertina, y costras, de una caverna cavada a mano en el Noreste de Kansas (Sec. 2 NENW, T2S, R 22E) se componen de aragonito y calcita. Si la edad estimada de la caverna es correcta, esto es 150-200 años, las estalactitas han crecido a razon de 0.20 a 0.15 milímetros por año a lo largo de los ejes verticales. Todas las espeleotemas contienen más de un porciento de estroncio (a base de análisis cualitativos espectrográficos de emisión). La cinética de flujo y evaporación de las aguas vadosas pueden dictar si el aragonito o la calcita es el polimorfo que se precipita de las aguas de la caverna.

\section{REFERENCES}

Broecker, W. S., Olson, E. A., and Orr, P. C. (1960) - Radiocarbon measurements and annual rings in cave formations. Nature, v. 185, pp. 93-94.

Coleman, J. C. (1945) - Stalactite growth in the New Cave, Mitchelstown, Co. Cork. Irish Naturalists' Jour., v. 8, pp. 254-255.

Dawkins, W. B. (1874) - Cave hunting. Macmillan and Co., London, 455 p.

Kriz, M. (1892) - Die Höhlen in den mährischen Devonkalken und ihre Vorzeit. K. K. Geol. Reichsanstalt Verh. Jahrb., v. 41, pp. 443-570.

Moore, G. W. (1962) - The growth of stalactites. Natl. Speleo. Soc. Bull., v. 24, part 2, pp. 95-106.

Pobeguin, Th. (1955) - Sur les concrétions calcaires observées dans la grotte de Moulis (Ariège). Compte Rendu Sommaire des Séances de la Soc. Géol. de France, pp. 1791-1793.

SIEGEL, F. R. (1965) - Aspects of calcium carbonate deposition in the Great Onyx Cave, Kentucky. Sedimentology, v. 4, pp. 285-299.

White, W. B. (1965) - Personal communication. 